\title{
Recyclable Treatment of Cyanide in the Mining Industry: The Way Forward
}

\author{
RO Anyasi ${ }^{1}$, HI Atagana ${ }^{2}$, JO Raymond Anyasi ${ }^{3}$, CS Ajah ${ }^{4}$ \\ $1,2,4$ University of South Africa- Pretoria, South Africa \\ ${ }^{3}$ Tshwana University of Technology- Pretoria, South Africa \\ eanyasro@unisa.ac.za; atagahi@unisa.ac.za; 215713512@tut4life.ac.za; 13755080@mylife.unisa.ac.za
}

\begin{abstract}
Cyanide is any chemical compound that contains monovalent combining group of carbon and nitrogen (CN). It breaks down some group of heavy metals resulting in the formation of complexes with such metals. The complexes that are formed are usually very stable even under mildly acidic conditions.Cyanide has been preferred in gold and silver mining worldwide, but its potential toxicity and environmental impact has been of health concern.Although cyanide can be recovered or degraded by several processes, it is still widely discussed and examined. Biological treatment of cyanide is a well-established environmental friendly alternative and has been commercially used at gold mining operations to complement the existing physical and chemical processes. Biological treatment techniques facilitate growth of microorganisms that are essential for the treatment procedures. The present study describes the environmental challenges of cyanide in the mining industry and provided an alternative use of biological processes to treat the chemical.
\end{abstract}

Keywords: Cyanide, Mining Industry, Environmental challenges, Biological treatment, microrganisms.

\section{Introduction}

Cyanide $\left(\mathrm{CN}^{-}\right)$is a single charged anion with a carbon and nitrogen atom joined with a triple bond forming a monovalent group. This group which consists of a carbon atom triple-bonded to a nitrogen atom is known as the cyano group [1].The compounds of cyanide which are regarded as salts of hydrocyanic acid, are highly toxic [2]. Cyanide ion is isoelectronic with carbon monoxide and with molecular nitrogen. Organic cyanides are usually called nitriles; in these, the $\mathrm{CN}$ group is linked by a covalent bond to a carbon-containing group, such as methyl $\left(\mathrm{CH}_{3}\right)$ in methyl cyanide (acetonitrile). Hydrocyanic acid; the inorganic cyanides, also known as hydrogen cyanide $(\mathrm{HCN})$ is a highly volatile liquid used to prepare acrylonitrile, which is used in the production of acrylic fibres, synthetic rubber, and plastics [1,2]. Cyanides are employed in a number of chemical processes, including fumigation, case hardening of iron and steel, electroplating, and the concentration of the compound ${ }^{3}$.

Cyanide is very reactive, forming simple salts with alkali earth cations and ionic complexes of varying strengths with numerous metal cations; the stability of these salts is dependent on the cation and on $\mathrm{pH}$ [4-5]. Cyanide also forms complexes with gold, mercury, cobalt and iron that are very stable even under mildly acidic conditions. However, both ferro- and ferricyanides decompose to release free cyanide when exposed to direct ultraviolet light in aqueous solutions. This decomposition process is reversed in the dark. The stability of cyanide salts and complexes is $\mathrm{pH}$ dependent, and therefore, their potential environmental impacts and interactions (i.e. their acute or chronic effects, attenuation and rerelease) can vary.

The process of extracting gold from ore with cyanide is called cyanidation. The reaction that ensures this process is known as Elsner's Equation or Adamson's equations, leaching occurs from this equations but most gold dissolves in the $2^{\text {nd }}$ known as the second equation of Adamson's:

$$
\begin{array}{r}
4 \mathrm{Au}+8 \mathrm{CN}-+\mathrm{O} 2+2 \mathrm{H}_{2} \mathrm{O}=4 \mathrm{Au}(\mathrm{CN}) 2-+4 \mathrm{OH}- \\
2 \mathrm{Au}+4 \mathrm{NaCN}+\mathrm{O} 2+2 \mathrm{H}_{2} \mathrm{O} 2 \mathrm{NaAu}(\mathrm{CN}) 2+\mathrm{H}_{2} \mathrm{O}_{2}+2 \mathrm{NaOH}
\end{array}
$$

Although the affinity of cyanide for gold is such that it is extracted preferentially, cyanide will also form complexes with other metals from the ore, including copper, iron, silver and zinc. The formation of strongly bound complexes such as 
those with iron and copper will tie up cyanide that would otherwise be available to dissolve gold. Copper cyanides are moderately stable; therefore their formation can cause both operational and environmental concerns, as wastewater or tailings from such operations may have significantly higher cyanide concentrations than would otherwise be present in the absence of copper [4-5]. High copper concentrations in the ore increase costs and lower recovery efficiencies by requiring higher cyanide application rates to compensate for reagent on those complexes with copper rather than gold. Hence, cyanidation is adversely affected by the presence of free sulfur or sulfide minerals in the ore [2]. Cyanide will preferentially leach sulfide minerals and will react with sulfur to produce thiocyanate. These reactions will also enhance the oxidation of reduced sulfur species, increasing the requirement for lime addition to control the $\mathrm{pH}$ at a sufficient level to avoid the volatilization of hydrogen cyanide $(\mathrm{HCN})$. Cyanidation techniques used in the gold industry today include heap or valley fill leaching, agitation leaching followed by carbon-in-pulp (CIP), and agitated carbon-in-leach (CIL). Cyanidation is best suited to fine-grain gold in disseminated deposits.

Compounds of cyanide are widely used by the mining industry to assist in the extraction of metals from rock. Cyanide is used to retrieve $90 \%$ of gold mined in the South Africa. Here, a dilute cyanide solution is sprayed on crushed ore that is placed in piles or mixed with ore in enclosed vats. The cyanide attaches itself to minute particles of gold forming water soluble, gold-cyanide compound from which the gold can be recovered [5]. Cyanide is used in a similar manner to extract silver from ores. In the extraction of non-precious metals, such as copper, nickel, cobalt, and molybdenum, cyanide is used in the milling and concentration processes to separate the desirable metals from the wastes. Consequently, cyanide breaks down and forms complexes with other metals or chemicals. These related compounds often end up as waste products that need to be dumped which can be just as toxic as cyanide itself, when they are not carefully monitored or regulated. The use of cyanide compounds by the mining industry, along with limitations in the analysis and monitoring of these compounds, raises serious concerns regarding environmental protection and public safety at mine sites that make use of cyanide processing. Both cyanide and acid-mine drainage finds their way into streams and rivers through accidental spills, discharges, dam overflows, and water runoff from dumps [6]. It can also seep or leach into groundwater. Cyanide-leach mines consistently contaminate water resources with cyanide and other pollutants placing human and environmental health at risk [7].Leftover cyanide in very small concentrations can harm birds and other wildlife that drink mine pond wastewater. Cyanide poisoning can occur through inhalation, ingestion, and skin or eye contact [8].

\section{The Chemistry of Use of Cyanide in the Mining Industry}

Cyanide is a naturally occurring compound that bonds with gold, allowing it to be brought into solution. It can easily be separated from gold for collection. This procedure is cost effective and simple. They have not been any suitable alternative for the extraction of gold since the inception of cyanidation [9]. Due to the occurrence of gold at very low concentrations in ores (less than $10 \mathrm{~g} / \mathrm{t}$ ) the use of aqueous chemical is a more economical extraction process. Gold is insoluble in water and therefore requires a complexant such as cyanide to stabilize its species in solution in the presence of an oxidant such as oxygen to dissolve gold [6]. During the process of extraction of gold from an aqueous cyanide solution it forms a gold cyanide complex by oxidizing the oxidant and cyanide complexation. There are alternative complexing reagents for gold mining such as Chloride, Bromide, Thiourea and Thiosulphate. These complexants form less stable complexes and present risks to health and the environment and however more expensive [10].

The various species of cyanide remain in tails streams from gold plants, on some operations the waste streams are processed through a detoxification process prior to tails deposition [11]. This reduces the concentrations of these cyanide compounds, but does not completely eliminate them from the stream. The two major processes used are the INCO licenced process and the Caro's acid process. Both processes oxidise cyanide to cyanate by utilizing oxidizing agents [10]. Cyanate is not as toxic as the cyanide ion, and can then react to form carbonates and ammonia:

$$
\begin{gathered}
\mathrm{CN}^{-}+[\mathrm{O}] \rightarrow \mathrm{OCN}^{-} \\
\mathrm{OCN}^{-}+2 \mathrm{H}_{2} \mathrm{O} \rightarrow \mathrm{HCO}_{3}^{-}+\mathrm{NH}_{3}
\end{gathered}
$$

\section{Environmental Challenges}

Cyanide is acutely and almost instantaneously poisonous ("toxic") to living organisms, including humans. Cyanide harms by blocking the absorption of oxygen by cells, effectively causing the victim to suffocate. Acute effects include 
rapid breathing, tremors, effects on the nervous system, weight loss and ultimately, death. One teaspoon of a $2 \%$ cyanide solution can kill a person. Regulatory documents often state that cyanide in water rapidly breaks down in the presence of sunlight into largely harmless substances, such as carbon dioxide and nitrate or ammonia [11]. Cyanide also tends to react readily with many other chemical elements and is known to form, at a minimum, hundreds of different compounds. Many of these breakdown compounds are generally less toxic than the original cyanide, but are still known to be toxic to aquatic organisms. These breakdown compounds may persist in the environment for an unknown period of time, and there is evidence that some forms of these compounds can accumulate in fish and plant tissues ${ }^{9}$. Fish are about one thousand times more sensitive to cyanide than humans. If fish do not die from limited exposure, they can still have reduced swimming ability, problems in reproducing (possibly creating deformed babies) and increased vulnerability to predators. In general, fish and other aquatic life are killed by cyanide concentrations in the microgram per litre (part per billion) range, whereas bird and mammal deaths result from cyanide concentrations in the milligram per litre (part per million) range. Chronic cyanide exposure may affect physiology, and levels of activity of many fish species, and may render the fishery resource non-viable [12].

The use of cyanide in mining is associated with several challenges [13]. The cumulative effects of these challenges lead to impacts such as (a) health and (b) environmental. The exposure of mine workers to cyanidemay lead to death ${ }^{14}$ or increase to disease risk due to movement of affected population with limited access to health services [15]. Cyanide is acutely toxic to humans. Liquid or gaseous hydrogen cyanide and alkali salts of cyanide can enter the body through inhalation, ingestion or absorption through the eyes and skin. The rate of skin absorption is enhanced when the skin is cut, abraded or moist; inhaled salts of cyanide are readily dissolved and absorbed upon contact with moist mucous membranes. Studies have suggested that these exposures results in the cognitive decline among children [16]. This practice also increases habitats for disease vectors such as mosquitoes and black flies [17]. The use of cyanide mine-polluted water for irrigation may have secondary effects on crops $^{18}$. The cyanide in mining health challenges context is also applicable aquatic organisms such as fish, shrimp etc, as this may have drastic effects on the aquatic ecosystem in general [19,20]. Extraction from surface and groundwater can directly impact ecosystems, resulting in competition in water accessibility with other water users and other resources have the potential to compound the future challenges of waste management [21]. Waterways and groundwater can be affected by different landscape transformation resulting frommining [22-2]. Environmental impacts associated with cyanide mining relate primarily to the degradation of water quality and aquatic ecosystem in these ways ; contaminations caused by mining wastes, pollutions caused by illegal dumping of mine wastes into water systems, gradual contaminant drainage caused by improperly sealed waste management sites and increase in soil erosion associated with land use changes [25]. The infusion of this chemical into the soil due to the use of cyanide polluted water for irrigation of crop may have secondary effects on soil, even in areas that are far from mining sites [18]

Cyanide from metal mining projects is a very challenging activity facing various mining organizations all over the world. It is the duty of and responsibility of the mining companies to maintain good practice and to ensure that the environment is safer from its operation. Since the inception of mining activities which dates back to the seventeen century [19], and the subsequent discovery that cyanide method of tailing are most economical, there have been report of the toxic effects of the residual cyanide trapped in the gold-mine tailings to the environment by the release of heavy metals for example mercury into the groundwater and surface water systems. This has sparked an outcry of people surrounding various mining areas as well the government in trying to protect the environment [26]. Reported cases of environmental disaster resulting from mining effluents from cyanide are:

* 130000 cubic meters of cyanide-tainted water flowed into lupes, while some eventually dripped into the Tisza and Danube rivers in Romania and Hungary respectively, covering over 400 kilometres ${ }^{27}$. This Romanian incident has become the most scandalous of cyanide spills because of the enormous scale of the disaster. It began when an unexpected heavy snowfall caused an overflow and break in a cyanide saturated tailings dam at the Aural Gold Plant on the $30^{\text {th }}$ of January, 2000. The environmental effects spanned three countries and infected over 400 kilometres of waterways. The legacy of the spill lives on in contaminated water, polluted land, and sick members of the local community where such havoc occurred.

* In Australia, the belief that Timbarra Gold Mine is world best-practice mine was doused when an overflow occurs from the toxic wastewater ponds into the surroundings. This was also followed by the death of over a thousand birds when North Parkes copper-gold mine fail to monitor cyanide levels at their mine. 
* Barrik Gold in 2004 was under scrutiny when the government report found out that large area around the Kalgoorlie Super Pit Fimiston tailings dam was hit by increased salinity, heavy metal contamination, cyanide contamination and elevated cyanide levels in the groundwater in Western Australia.

* Ten miners were killed by cyanide spill after collapse of a tailing dam at the Harmony mine in South Africa; this was reported by Gold Album in 1994.

* In the San Juan Mountains of south-western Colorado at Alamosa River, cyanide as well as heavy metal leakage from the Summitville gold killed all aquatic life along a 27 stretch of the river as was reported in 1992.

* Another incidence occurred in 1997 when failure of leach pad structure at the Gold Quarry mine in Nevada released about a million litres of cyanide-laden wastes into two lateral streams, killing over 11,000 fish along $80 \mathrm{~km}$ stretch of the Lynches River.

* About 3.2 billion litres of cyanide-laden tailings were released into Essequibo River in Guyana in 1995, when a dam collapsed at the Omai gold mine. The Pan American Health Organization study indicated that all aquatic life in the 4 $\mathrm{km}$ long stream from the mine to the Essequibo River was killed.

* In another report from Vietnam, cyanide leakage from tailing polluted the central Quang Nam province causing public health disruptions. Many of the residents of that area complained of skin irritation and itching when using water from the stream. Deformed and retarded children were also giving birth to by the people of that area.

* Long term legacy of cyanide accidents can be crippling to the local community harbouring the mines. Although the mining industry has long argued that cyanide in water will break down under ultra-violet sunlight into largely harmless substances, Dr Mathew Jeffrey a chemical engineer at the Australian Monash University agrees that cyanide itself isnot a problem long-term, because it does degrade reasonably quickly [28]. But where the problem comes from is that cyanide is able to immobilise heavy metals, so that if the solution is let out into the aquatic environment then you have heavy metals which persist for a much longer period of time. So a lot of the problem with the cyanide spills is the heavy metals which are spilt at the same time [29]. In the case of Romania these metals can build up along the riverbeds and banks, and cause severe long term environmental impacts on the aquatic life and water quality. This in turn can affect human health and economic stability as the agricultural, fishing and tourism opportunities disappear.

Such long and short term effects have resonated worldwide, as have been narrated in this work.

Various hazards caused by cyanide to human, wildlife, aquatics as well as livestock are well documented ${ }^{28}$. USEPA ${ }^{30}$, reported immensely on the killing of fresh water fish by cyanide wastes, and according to the Federation of American scientists' cyanide is deadly to human even in a small dose: ingesting a small amount of the compound usually results to rapid breathing, restlessness and sometime dizziness, weakness, headache, nausea, vomiting as well as increased hearth rate. Prolonged exposure to the substance to about 1 part in 500 in an enclosed space could lead to convulsions, low/decreased blood pressure, loss of consciousness, lung injury, and death in about 8-10 minutes depending on exposure and duration. It is reported that one tea spoon of a $2 \%$ cyanide solution is needed to kill a person [30]. Other health effects as a result of high ingestion of cyanide include thyroid gland defect, which lead to cretinism and over activity of the lungs. It is as a result of this negative impact of cyanide that necessitated the enacting of Cyanide Code and other measures and programs to enable gold mine industries to promote the responsible management of cyanides used in their mines in other to enhance the protection of human and the environment of the potential impacts of the contaminant. Even though most of these established measures stipulate that the companies involved be subjected to independent auditors to maintain their adherence to these requirements, most of the mine companies usually avoid the process [26].

10

\section{Government Deliberation}

In October 2004, Lee Rhiannon from the New South Wales of Australia (NSW), proposed to the parliament to pass the Mining Amendment (Cyanide Leaching) Bill 2004 which would try to introduce a total ban on the chemical in leach mining activities. However, the proposed bill is continually been debated and Rhiannon is of the opinion that the outcome will not be favorable but is pleased that the political discussion may have increased public awareness [31]. But why would a government allow the use of cyanide to continue despite historical testimonies of toxic accidents? Both the government and mining companies' alike claim that gold mines will create employment opportunities for the host communities, thereby injecting money into the local economy and as well supporting global economic development. A claim that cyanidation creates employment and enables the stimulation of economic growth of the states, is an illusion considering the fact that 
gold production which services the jewelry industries. It has been reported that about $80 \%$ of newly mined gold each year goes into jewelry fabrication [32], yet the cost of such ornaments continues to rise causing cash divergence only to the rich. The total quantity of gold reserve in the World Bank can last the entire world population for up to a decade, hence the world really do not need this menace caused by such process to the environment. When it comes to sustainable mineral development, you will find no stronger supporter than the government states. But this adversaries contest the truth of the political rhetoric, meaning that those jobs are completely overestimated because most of those are specialized or could be outsourced from a different area. The truth still remains that governments allow water, land, indigenous and community land rights to be stepped all over for the sake of votes or for deals they make with corporations for profit or greed, and it is not enough to show evidence that something is hazardous [28]. The problem with it is that the jobs are short lived, so as soon as the project is finished the region gets deflated. In the European Commission under article 14, companies are made to put in place financial guaranties to enable clean-ups after the mine has finished. This means that as long as you have the financial strength, you would be given the guarantees to operate, and what happens thereafter is meant to be decided by our ailing environment. This is more harmful than letting the region find a long-term sustainable solution to the problem. So then what kinds of solutions or alternatives are there to the cyanide leach mining debate? The future trends in mining and processing may compound the challenges of waste management, as the lower ore grades increases the ratio of waste produced for a given unit of resource [33].

\section{Alternatives}

They have been ongoing research on a non-toxic chemical called Thiosulfate that would behave like cyanide in the gold leaching process. But such discovery is still in the laboratory stage and could still take some time before it can be tested in a pilot scale operation, let alone employing at the industrial level. However, this compound is a lot more complicated than cyanide, which is one of the things that has delayed emphasis on the development at this stage because Thiosulfate is not really that stable [34].

However, for campaigners, finding a chemical substitute is simply a band-aid solution for a much deeper wound. Our consumer driven society is at the core of this issue, because it is human consumption that demands that gold be retrieved from the earth in the first place [27]. The question that needs to ask is"why not look at recycling gold and other metals from our used consumable goods as opposed to throwing them away, should human still expect the earth to give an infinite supply of resources and then stick them back into landfill?"

Now the use of cyanide is banned in some countries for example in the Czeslovakia Republic, Turkey, Hungary and in some states of the US. It is of paramount important that every other country plagued by this environmental disaster should encourage such measure. Although European commission rejected a proposal for such ban, insisting that the existing regulations make provision for adequate environmental and health protection, hence the implementation of the "Cyanide Code", a program that aims to reduce environmental impacts with third party audits of a company's cyanide management is of importance in every part of the world where cyanide leaching is an issue [35]. Since there have not been any suitable alternatives for this process in existence, the ban means no more production of gold. Therefore, further decisions have to lie between (a) further production and endangering of people's health and the environment and (b) ban for people's right to live in a healthy environment.

\section{Treatment Processes for Cyanide Effluents}

There are several treatment processes that have been used to treat cyanide effluents solutions or slurries with low levels of cyanide and its related compounds $[13,36]$. Cyanide treatment processes most times are classified as a destruction-based process versus the physical processes of cyanide recovery as well as activated carbon sorption. In a destruction process, either chemical or biological reactions are utilized to convert cyanide into other less toxic compounds ${ }^{3}$.

\section{Chemical and Physical Processes}

Most appropriate cyanide treatment process involves the consideration of many factors; which includes that the chemical characterization of the effluents or slurry, quantification of the volumes to be treated, consideration of the environmental setting, and review of the applicable regulations ${ }^{36}$. These treatment processes operate on the principle of converting cyanide into more or less toxic compounds through an oxidation reaction. Chemical treatment processes includes Sulphur dioxide and air, Hydrogen peroxide, Alkaline and breakpoint chlorination. These processes are applied to 
achieve effluent cyanide levels suitable for discharge ${ }^{3}$. They are simple processes capable of operating over wide $\mathrm{pH}$ ranges, while producing environmentally acceptable means. These processes have the advantage of treating tailings slurry and process solutions [36]. The disadvantages of these treatment processes is that residual products such as oxidizing thiocyanate and ammonia to nitrogen gas needs to be treated as well using other treatment processes making them more expensive and time consuming [36,37]. The constituents of concern are not only cyanide and metals, but also thiocyanate, ammonia, and nitrate. These are secondary concerns with elevated levels of total dissolved solids and sulphate, leaving the environment more contaminated ${ }^{3}$. Biological treatment was chosen because the chemical oxidation processes involving hydrogen peroxide and sulphur dioxide do not remove thiocyanate, ammonia, and nitrate. Although breakpoint chlorination may remove these three constituents, it is very expensive and produces residual total dissolved solid (TDS) and chloride concentrations that are toxic and too high for freshwater fish to tolerate [3,38]. Other new extractants that have been examined include thiosulfate $\left(\mathrm{S}_{2} \mathrm{O}_{3}{ }^{2-}\right)$, thiourea $\left(\mathrm{SC}\left(\mathrm{NH}_{2}\right)_{2}\right)$, iodine/iodide, and ammonia. Thiourea has been implemented commercially for ores containing stibnite [39].

Emerging sciences are developing new technologies that may make cyanide use unnecessary in all mining processes [40]. One of the alternative oxidants for the degradation of cyanides that has been attracting industrial interest is Caro's acid - peroxomonosulphuric acid $\left(\mathrm{H}_{2} \mathrm{SO}_{5}\right)$ [41]. Caro's acid converts cyanide to cyanate which then hydrolyses in water to ammonium and carbonate ions. The Caro's acid process produces effluents at concentration levels below $50 \mathrm{mg} / \mathrm{L}$, which is generally suitable for discharge to tailings. The best application of this process is generally with tailings slurries containing low to moderate initial levels of cyanide and when treated, cyanide levels of about 10 to $50 \mathrm{mg} / \mathrm{L}$ are required $^{35}$. In the current state of affairs, over 90 mines worldwide now use an Inco $\mathrm{SO}_{2}$ /air detoxification circuit to convert cyanide to the much less toxic cyanate before waste is discharged to a tailings pond [42].

\section{Biological Processes}

Bulk of cyanide occurrence in environment is mainly due to metal finishing and mining industries. Although cyanide can be removed and recovered by several processes, it is still widely discussed and examined due to its potential toxicity and environmental impact. From an economic standpoint, the biological treatment method is cost-effective as compared to chemical and physical methods for cyanide removal. Several microorganisms, bacteria such as Nocardia $s p$. and Rhodococcus sp., fungi such as Aspergillus sp. and Fusarium sp. and algae such as Arthrospira maxima and Scenedesmus obliquus, possess enzymatic mechanisms able to bioremediate free cyanide and cyanide complexes [36,44]. Most microbial species including the afore-mentioned can effectively degrade cyanide into less toxic products and detoxify the intracellular build-up of synthesized organic cyanides by using their inherent cyanide-metabolizing pathways. Many microorganisms have specific enzyme systems and pathways to degrade cyanide. Most species of bacteria and fungi can absorb cyanide and use it as nitrogen and carbon source, generally through an $\mathrm{NH}_{3}$ intermediate [45]. Organic cyanides are toxic to a wide range of microorganisms, including fungi, bacteria (anaerobes particularly methanogens) and algae, but the toxicity of such cyanides depends on their form and nature and also on the presence/absence of cyanide-metabolizing enzymes. Co-contamination of other pollutants can also affect the biodegradation of cyanide by manipulating the original microbial populations, selecting for, or inhibiting, the growth of particular organisms [46,47]. Some bacterial strains, such as Pseudomonas spp., are killed by mild cyanide concentration. Rhodanese from B. sfearofhermophilus appears to have great potential for the degradation of cyanide, but it has not been tested under great potential for the degradation of cyanide under field conditions because of its limited stability. Cyanidase and rhodanese enzyme systems may be utilized to treat waste streams contaminated with metallic cyanides and other cyanide complexes by using protective devices to keep the enzymes stable and reactive. Availability of nutrients may affect the bioremediation of cyanide compounds, the presence of oxygen is an important issue in the microbial mineralization of cyanide hence, oxygen is consumed during some of the degradation pathways of cyanide ${ }^{46}$. The $\mathrm{pH}$ may be a particularly important factor in the bioremediation of cyanidecontaminated soils. The $\mathrm{pH}$ optima for bacterial and fungal growth are typically 6-8 and 4-5, respectively, and cyanide degrading enzymes generally have $\mathrm{pH}$ optima between 6 and 9, therefore, extremes of $\mathrm{pH}$ may have a significant effect on biodegradation. However, Fusariumsolaniand mixed cultures of fungi, including F. solani, Fusariumoxysporum, Trichodermapolysporum, Scytalidiumthermophilumand Penicillinmiczynski, were capable of degrading iron cyanides at $\mathrm{pH}$ 4 [48]. The cyanide degrading enzymes are formed by mesophilic bacteria that are often isolated from soil at a temperature range of $20^{\circ} \mathrm{C}-40^{\circ} \mathrm{C}$, meaning that temperature is an essential factor in the biodegradation of cyanide. 
Biological treatment of cyanide is the conversion of free and metal complexes cyanides by microorganisms into intermediates $^{3}$. In this process, freed metals are either adsorbed within the biofilm or precipitated from solutions such as the oxidative breakdown of cyanides and thiocyanate, and subsequent sorption and precipitation of free metals into the biofilm [36]. Cyanide and thiocyanate are degraded to a combination of ammonia, carbonate, and sulphate while ammonia is converted to nitrate through the conventional two-step nitrification process with nitrite as the intermediate. Various Pseudomonas species are responsible for complete oxidation of cyanide, thiocyanate, and ammonia. The ease with which the metal cyanide complexes are degraded follows their order of chemical stability with free cyanide being the most readily degradable and iron cyanide the least. The degradability of the other metal cyanide complexes of $\mathrm{Zn}, \mathrm{Ni}$, and $\mathrm{Cu}$ are in between. Iron cyanides have been shown to degrade to a minor extent as well as be adsorbed within the biomass $[3,36]$.

Other researchers at Northwestern University recently stumbled upon a solution that uses cornstarch instead. Cornstarch is cheap, biologically friendly and contaminant-free. A team of scientists led by Sir Fraser Stoddart discovered this method by accident while playing around in their laboratory [49]. A Post-Doctoral fellow named Zhichang Liu was trying to make three-dimensional cubes out of gold and starch, aiming to use them as storage containers for gases and small molecules. But a liquid mixture of dissolved gold-bromide salts and a starch-derived sugar rather than forming cubes formed needles instead. This was strange, so the team decided to try to replicate it and tested different forms of sugars. They found out that alpha-cyclodextrin, a cyclic starch fragment with six glucose molecules, is the best way to isolate gold. The interaction between the starch fragment and the gold allows the precious metal to be selectively recovered from other materials, including platinum, palladium and others. By this, a process has already been developed to isolate gold from scraps, and the hope is that this will lead to an environment friendly, cheap way to recover gold from ores.

Biological treatment provides the most efficient and economical means of removing nitrogen from wastewater in the form of ammonia or nitrate [3]. The microorganisms involved in the biological treatment of cyanide and thiocyanate usually include a heterogeneous mixture of commonly found indigenous soil bacteria which have through continuous extended exposure adapted to the treatment of these compounds.A mixed population of bacteria is alternately exposed to aerobic conditions for nitrification and then anoxic conditions for denitrification. During nitrification, ammonia is first oxidized to the intermediate nitrite slowly and then rapidly to nitrate. In denitrification, the nitrate is then reduced to nitrogen gas resulting in complete removal of nitrogen from the solution being treated. The various microbial populations involved in the cyanide degradation and ammonia nitrification stages are normally non-competitive. Cyanide and thiocyanide, if present, serve as source of energy and carbon for the bacteria degradation and can be toxic to the nitrifying bacteria. Ammonia and bicarbonate serve as carbon and energy sources for the nitrifying bacteria. An upset in the effectiveness of cyanide or thiocyanate degradation stage will adversely affect the nitrification stage with recovery of the nitrifying bacteria being much slower than recovery of cyanide degraders [36].

Temperatures is relatively important in the biological degradation of cyanides and their products for a complex interaction of chemical, physical, and biological reactions, which includes hydrolysis, precipitation, photolysis, volatilization, dilution, and microbial degradations $[1,18,36]$. The formation of thiocyanate during the cyanidation process constitutes a major cyanide demand. The thiocyanate produced, along with cyanide, represents the primary carbon source for the bacteria treatment process. The metals of interest (iron, copper, nickel, and zinc) are found naturally in the ore and are solubilised by cyanide during the cyanidation process, which forms the metal complexes cyanides. The metal complexes cyanides are divided into two categories.

The metals released during the oxidation of the metal complexes cyanides are removed from solution through chemical precipitation and bacterial adsorption into the biofilm. The alkalinity of the raw wastewater is important as insufficient alkalinity results in incomplete nitrification within the treatment process [15]. The bacterial breakdown of thiocyanate and cyanide within the treatment process coupled with inherent ammonia in the raw wastewater produce transient ammonia concentrations as N. Since the raw wastewater alkalinity is insufficient to meet nitrification demands, alkalinity is supplied in the treatment process through the addition of soda ash $\left(\mathrm{Na}_{2} \mathrm{CO}_{3}\right)$. Extremely high hardness values $\left(650-750 \mathrm{mg} / \mathrm{l}\right.$ as $\left.\mathrm{CaCO}_{3}\right)$ of the influent wastewater result from excessive amounts of lime consumed in the cyanidation process for $\mathrm{pH}$ control and from the massive quantities of cement employed in the cement-sand backfill procedure. The backfill procedure is utilized in filling mined out areas to provide support and improve structural integrity of the underground environment $[13,14]$.

Destruction of cyanide by microorganisms from tailings solutions and other process in wastewaters is a proven alternative to traditional chemical and physical processes. Destruction of cyanide by microorganisms in gold and silver mill effluents 
is a natural process that can be readily exploited and engineered to accommodate the large flows and elevated cyanide containing solutions generated at commercial precious metals operations [3,50]. Bacteria found to be involved in the processes are mostly gram-negative bacteria such as Pseudomonas, Achromobacter, Flavobacterium, Nocardia, Bdellovibrio, Mycobacterium, and two nitrifiers, Nitrosomonas and Nitrobacter $[4,13]$.

\section{Advantages of Biological Processes}

Despite the efforts of mining companies to replace cyanide compounds and degrade by-product of the cyanide oxidation, (CNO), yet mining processes generate ammonia, a potentially toxic compound [49,50]. Environmental concerns in mining include cyanide in aqueous discharges from mills and heap leach operations. Biological processes, which might satisfy both the needs of extraction and environmental control, have been proven at large scale in well-understood and engineered systems in several countries ${ }^{4,13}$. Therefore, biological processes are more environmentally friendly than conventional processes. In many cases, cleaner effluents would then be achievable at lower cost using biological processes $[3,36]$. However, if minimum effluent standards are currently being met by using conventional treatment, a switch to biological treatment is likely to be more economical [17]. Biological processes of cyanide and associated components such as ammonia and thiocyanate in gold mill effluents is a natural process and can be readily exploited to handle large flows and cyanide concentrations found in commercial gold operations. Commercially, applications such as in-plant treatment as an alternative to chemical processes and in situ cyanide destruction of spent heap leach piles are in use ${ }^{4,51}$. Biological treatment or biodegradation processes have been adopted in the mining industry due to the success of the treatment plants built $[36,37,52],$. In these plants, an aerobic attached growth biological treatment is used to remove cyanide, thiocyanate, cyanate, ammonia, and metals from tailings impoundment decant solution prior to discharge into natural waters [3].

\section{Biological Applications}

Biodestruction has been effective in the treatment of varying levels of cyanide and thiocyanate in full-scale systems at two Home-stake Mining Company (HMC) operations. At the Homestake mine in Lead, South Dakota, an attached growth biological treatment facility consisting of 48 rotating biological contactors has been continuously treating several million gallons per day of wastewater and is capable of treating thiocyanate concentrations exceeding $100 \mathrm{mg} / \mathrm{l}$ [4]. At the HMC Nickel Plate mine in British Columbia, the existing carbon-in-leach (CIL) circuit was converted into a three-stage combined aerobic/anaerobic activated sludge process capable of treating about $200 \mathrm{gpm}$ of tailings pond water with thiocyanate concentrations exceeding $1000 \mathrm{mg} / \mathrm{l}$, along with ammonia and nitrate levels of several hundred mg// ${ }^{36,38}$. Both the large-scale biological treatment systems discussed here are producing effluent thiocyanate concentrations well below 5 $\mathrm{mg} / \mathrm{l}$ on a continuous basis. Homestake developed a passive in situ anaerobic biological process termed the Biopass System for the treatment of residual cyanide and other constituents in the draindown from a large heap leach pad located at its Santa Fe mine [4]. The use of the in situ passive biological process is becoming a preferred approach for treatment of draindown and seepage at heap leach operations [53,54].

Although cyanide is readily degraded by aerobic bacteria, thiocyanate is not readily removed through anaerobic biological treatment. In addition, anaerobic biological treatment is slower and more susceptible to toxic upsets resulting from exposure to other constituents present in the solution being treated. As a result, the proper approach is to use an attached or suspended growth aerobic biological treatment process for thiocyanate removal. The most critical environmental factors associated with biological treatment include $\mathrm{pH}$, temperature, oxygen levels, and nutrient availability $[3,36]$. In this particular application, the $\mathrm{pH}$, oxygen levels, and nutrient availability can be controlled in routine ways. As such, the solution temperature should be adequate to support biological growth and treatment. The need to heat the reclaim solution in a simple and economical manner is a challenge. It may be possible to use some of the excess heat generated in other processes to raise the reclaim solution to the desired temperature. The only limiting nutrient in solution is phosphate, which is conveniently added in concentrations ranging from about 1 to $5 \mathrm{mg} / \mathrm{l}$ using concentrated phosphoric acid. There is also a need for oxygen, which is accomplished through either natural or artificial aeration of the solutions. The minimum dissolved oxygen needed is on the order of $2.0 \mathrm{mg} / 1$ [4,13]. In addition to these environmental factors, the presence of toxic and inhibitory substances reduces the effective rate of degradation to below its optimal level. There are a variety of attached and suspended growth processes available for the aerobic biological treatment of cyanide and thiocyanate. These include rotating biological contactors, packed beds, biological filters, sequencing batch reactors, facultative lagoons, and activated sludge systems. In these particular applications due to the low cyanide and thiocyanate levels, there may not be 
sufficient biomass production to allow the use of suspended growth systems. An attached growth system which is simpler to operate and less susceptible to upsets would be the most suitable for the treatment of the lower levels of cyanide and thiocyanate anticipated in the reclaim solution $[2,20]$.

\section{Conclusion and Suggestions on the Current State of Affairs}

In mining operations, several water management and treatment alternatives are considered which are already in use at the mine. Biotechnological treatment approaches are under various stages of development; however, many technologies have been proposed and some processes currently compete with conventional technologies and are likely to do better according to regulatory standards. Processes which have been applied commercially includes: in-plant cyanide destruction; in situ cyanide destruction of spent heap leach piles; metal and sulphate removal using active (in-plant) sulphate reduction; and limited use of passive processes such as wetlands and ecological engineering for metals polishing [52]. At least chemical treatment processes and a few biological processes are available for removing cyanide from mining effluents. Cyanide treatment currently relies on chemical technologies, but recently biological treatment processes have been used successfully in large-scale operations. Hence, biological processes can be reliable and economically viable. Furthermore, many proposed alternatives to the use of cyanide in mining have been a matter of increased deliberations, but most have been rejected by industry because of high cost of reagent and non-effectiveness (inefficiency of gold recovery). The unique chemical behavior and toxic nature of cyanide and associated compounds, combined with the risk of serious mine waste spills suggest that there are persisting uncertainties which calls for closer study [48, 53]. The metabolic activities of various microorganisms can be transformed to remediate cyanide compounds in the contaminated environment. Identification of new microorganisms with respect to their degradation abilities could be a step in the right direction. Advancements in engineering processes (biochemical Engineering), are likely to improve the biological treatment of cyanide wastes when the biochemical and ecological aspects of the relevant microorganisms are better understood. Also development of more microbial processes that is resourceful in extreme environmental conditions such as low $\mathrm{pH}$ and toxicity of contaminants is required to guarantee a technology that can reduce cyanide pollution [54].A wide range of biological remediation methods are already in use but newly developed techniques are expected as there is emergence of new environmental challenges. Environmental biotechnology has a lot of economic and environmental benefits as modified organisms are used to bioremediate the contaminated environment under controlled conditions.

Nonetheless, there is need for continued measuring, monitoring and addressing of cumulative impacts of cyanide in minning [55,56-70]. Studies have proposed the promotion of information-based strategies like educational outreach programmes, including sufficient funding and commitment of stakeholders [13,68,71-73]. Arguments for the greater understanding and emphasis on the intersecting nature of water and human rights importance from a sustainable development perspective have been laid [58,74-75]. Discussions on the implication for current and future practices with the urgency and need for the industry to adopt new approaches have been made ${ }^{56,84-88}$. The future trends in mining and processing may compound the challenges of waste management, as the lower ore grades increases the ratio of waste produced for a given unit of resource [33,57, 76-77].

\section{References}

[1] N. N. Greenwood, A. Earnshaw, Chemistry of the Elements (2nd Edn.), Oxford:Butterworth-Heinemann. ISBN 07506-3365-4. Pg. 48. 1997.

[2] G. L. Miessler, D.A. Tarr, "Environmental and Health Effects of Cyanide,". International Cyanide Management Institute. 2006. Retrieved 4 August 2019.

[3] R. R, Dash, A. Gaur, C. Balomajumder, "Cyanide in industrial wastewaters and its removal: A review on biotreatment," J Haz Mat, vol. 163, no. 1, pp. 1-11 2009.

[4] Y. Chang, G. Achari, C. Langford, "Effect of Cocontaminants on the Remediation of PCB-Impacted Soils by Hydrogen Peroxide". Pract Period Haz Toxic Rad Waste Manage, vol.14, no. 4, pp. 266-268, 2010.

[5] J. Marsden, I. House, "The chemistry of gold extraction," Ellis Harwood Limited, Hertfordshire, United Kingdom. Pg. 47. 1993.

[6] C. M Flynn, S. L. McGill, "Cyanide Chemistry-Precious Metals Processing and Waste Treatment, U.S. Bureau of Mines,” NTIS Publication PB96-117841, pp. 1-297, 1995. 
[7] M. M Botz,. "Aglobal perspective of cyanide, presented at 2001.” Annual SME Conference, Denver, Colorado, pp. $16,2001$.

[8] A. Smith, T.I. Mudder, “An environmental perspective on cyanide,” Mining World News, vol. 6, pp. 1-22. 1994.

[9] Agency for toxic substances and disease registry (ASTDR) "Toxicological profile forcyanide prepared.by research triangle institute for the US department of health and human services," Atlanta, Georgia, pp. 40-56, 1995.

[10] A. Akcil "Destruction of cyanide in gold mill effluents: biological versus chemical treatments". Biotechnol. Adv, vol. 21, no. 6, pp. 501-511, 2003.

[11] A. Akcil, A. G. Karahan H. Ciftci, O. Sagdic, "Biological Treatment of Cyanide by Natural Isolated Bacteria (Pseudomonas sp.)," Min Engi, vol. 16, no. 7, pp. 643-649, 2003.

[12] A. Akcil, T Mudder "Microbial destruction of cyanide wastes in gold mining: process review", Biotechnol Lett, vol. 25, no. 6, pp. 450-5, 2003.

[13] R. A. Miserendino, B. A. Bergquist, S. E. Adler, J.R.D. Guimarães, P.S.J. Lees, W. Niquen, P.C. Velasquez-Lopez and M.M. Viega, "Challenges to measuring, moinitoring, and addressing the cumulative impacts of artisanal and small-scale gold mining in Ecuador", Res Policy, vol 23, no. 2, pp. 136-142, 2013.

[14] N. Jennings, "Social and Labour Issues in Small-Scale Mines: Report for Discussion as Tripartite Meeting on Social and Labour Issues in Small Scale Mining.International Labour Organization", Geneva, Switzerland. Pg. 1.12, 1999.

[15] Z. Aksu, A. Calik A.Y, Dursun., Z. Demircan, "Biosorption of iron (III)-cyanide complex ions on Rhizopus arrhizus: application of adsorption isotherms", Process Biochem, vol. 34, no.5 , pp. 483-491, 1999.

[16] Ó. Betancourt, R Barriga, J.R.D. Guimarães, E. Cueva and S. Betancourt, "Impacts on environmental health of smallscale gold mining in Ecuador. In: Charron, D. F. (Eds.), Ecohealth Research in Practice, Insight and Innovation in International Development", New York, Springer. Pg. 119-130. 2012.

[17] B. Ballantyne, "Toxicology and hazard evaluation of cyanide fumigation powders", Clinical Toxicol, vol. 26, no. 5-6, pp. 325-335, 1988.

[18] 18. J. Appleton, T. Williams, M. Carrasco, "Fluvial contamination associated with artisanal gold minning in the Ponce Enriquez, Portovelo-Zaruma and Nambijaareas Ecuador". Water air soil poll. 31, no. 1, pp. 19-39, 2001.

[19] N. Tarras-Wahlberg, S. Lane, "Suspended sediment yield and metal contamination in a river catchment affected by ElNiño events and gold mining activities: the Puyango River Basin", southern Ecuador. Hydrol Proc, vol. 17, no. 15, pp. 3101-3123, 2003...

[20] J.R.D. Guimaraes, O. Betancourt, M.R. Miranda, R. Barriga, E. Cueva S. Betancourt, "Long range effect of cyanide on mercury methylation in a gold mining area in southern Ecuador", Sci Total Environ, vol. 409, no. 23, pp. 5026-5033, 2011.

[21] 55. D. Brereton, C. J. Moran, G. McIlwain, J. McIntosh K. Parkinson, "Assessing the cumulative impacts of mining on regional communities: an exploratory study of coal mining in the Muswellbrook area of New South Wales", Brisbane Centre for Social Responsibility in Mining, Center for Water in the Minerals Industry, the University of Queensland. Pg. 18-27. 2008

[22] 22. D. Franks, "Consuming Landscapes: Towards a Political Ecology of Resource Appropriation" PhD thesis, Griffith School of Environment, Centre for Governance and Public Policy: Brisbane, Australia. Pg. 20-66. 2007.

[23] 23. P. Loeb, "Moving Mountains", University Press of Kentucky, Lexington, Kentucky. Pg. 19. 2007.

[24] 24. G. Bridge, "Contested terrain: mining and the environment" Annual Rev Environ Res, 29, pp. 205-259. 2004.

[25] 25. SGAB-"Prodeminca, Monitoreo Ambientaldelas Áreas Minerasenel Sur De Ecuador, 1996-1998: Proyecto de Desarrollo Mineroy Control Ambiental, Sub- Component 3.1”, Report SES no.R-Ec-E-9.46/3.1-9810-069.Quito: Sweedish Environmental Systems, pp 1-20. 1998.

[26] 26. International Cyanide Management Institute International Cyanide Management Code for the Gold Mining Industry $88816^{\text {th }}$ Street NW-Washington DC.http://www.cyanidecode.org/signatorycompanies.php Accessed 18/09/2020. 2006.

[27] 27. C. Nicholas, "Dirty Gold: The toxic legacy of cyanide leach mining, Minig Australia 2004", University of Technology, Sydney, pp. 1-5. 2004.

[28] 28. R. Cellan, A. Cox, R. Uhle, D. Jenevein, S. Miller T. Mudder, 1998. „The biopass system phase II: full scale design and construction" In: Mudder TI, Botz M, editors. The cyanide monograph. 2nd ed. London. Mining Journal Books: Published in The Cyanide Compendium on CD, pp. 473-83. 
[29] 29. Saturday Star, $28^{\text {th }}$ Sept, 2013. Water taints life in cradle, pp. 2.

[30] 30. P. A. Doherty, V. H. Ferm R. P. Smith, "Congenital malformations induced by infusion of sodium cyanide in the golden hamster”, Toxicol Appl Pharmacol, vol. 64, no. 3, pp. 456-464, 1982.

[31] 31.A. T. Dumestre; J. P. Chone, J. Berthelin, "Cyanide degradation under alkaline conditions by a strain of Fusarium solani isolated from contaminated soils" Appl. Environ. Microbiol, vol. 63, no. 7, pp. 2729-2734, 1997.

[32] 32. Dirty Gold mining, "The toxicity legacy of cyanide leaching" http://www.journalism.uts.edu.au/miningoz, Accessed 23/09/2013, pp. 13. 2006.

[33] 33. R. Eisler, Cyanide hazards to Fish, Wildlife, and invertebrates: A Synoptic Review, Biol. Report, vol. 85, no. 23, pp. 1-23, 2004.

[34] 34. L. Jarup, "Hazard of heavy metal contamination”. British Med. Bull, vol. 68, no. 12, pp. 167-182. 2003.

[35] 35. M.F. Bitala, C. Kweyunger, M.L.K. Manoko, "Levels of heavy metals and cyanide in soil, sediment and water from the vicinity of North Mara Gold Mine in Tarime District, Tanzania. A report presented to CCT" Accessed 17/09/2020, pp. 24-33, 2009.

[36] 36. M. I. Ezzi, J.M. Lynch, "Biodegradation of cyanide by Trichoderma spp. and Fusarium spp.," Enzyme Microb. Technol, vol. 36, vol. 7, pp. 849-854, 2005.

[37] 37. T. Mudder, M. Botz, A. Smith, “The cyanide compendium,” London: Mining Journal Books; On CD-ROM, pp. 1$15,2001 \mathrm{a}$.

[38] 38. B. Given, B. Dixon, G. Douglas, R. Mihoc, T. Mudder, Combined aerobic and anaerobic biological treatment of tailings solution at the Nickel Plate Mine. The cyanide monograph. London: Mining J. Books, pp. 1-20. 1998.

[39] 39. D. M Franks, D.V. Boger, C.M. Cote, D.R. "Mulligan Sustainable development principles for the disposal of mining and mineral processing wastes," Res Policy, vol. 36, no. 2, pp. 114-122, 2010.

[40] 40. D.M. Franks, D. Brereton and C.J. Moran, "Cumulative social impacts. In: Vanclay, F., Esteves, A.M. (Eds.), New Directionsin Social Impact Assessment: Conceptual and Methodological Advances," Edward Elgar Publishing, Cheltenham, Glouce- ster, UK, pp. 202-220. 2011.

[41] 41. Global Mining Campaign, "The Impact of Hardrock mining on the Environment and Human Health,"International Meeting, Warrenton-Virginia, USA, pp. 12, 2001.

[42] 42. L. Russell, M. Botz, S. Miller T. Mudder, "Life-cycle management of waste at golden cross," Min. Environ Mant, vol. 27, no. 3, pp. 7-10, 2000.

[43] 43. R. Bazell, J. Pauley, Scientist Norman Haber Discovers Way to Move Molecules, Pull Gold from Ore" NBC Today Show, New York, NY: NBC Universal. Pg. 1-12.. Accessed 05/09/2019 from NBC Learn: https://archives.nbclearn.com/portal/site/k-12/browse/?cuecard=39886, pp. 4, 1986.

[44] 44. M.A. Rao, R. Scelza, R. Scotti L. Gianfreda, "Role of Enzymes in the Remediation of Polluted Environments," J Soil Sci Plant Nut, vol. 10, no. 3, pp. 333-353. 2010.

[45] 45. C.J. Knowles, "Microorganisms and cyanide," Bacteriol Rev, vol. 40, no. 3, pp. 652-680, 1976.

[46] 46. J. Baxter, S.P. Cummings, "The current and future applications of microorganism in the bioremediation of cyanide contamination," Antonie van Leeuwenhoek, vol. 90, no. 1, pp. 1-17, 2006.

[47] 47. C. M. Kao, K. F. Chen, J. K. Liu, S. M. Chou, S. C. Chen, "Enzymatic degradation of nitriles by Klebsiella oxytoca," Appl Microbiol Biotechnol, vol. 71, no. 4, pp. 228-233, 2006.

[48] 48. M. Barclay, A. Hart, C. J. Knowles, J. C. L. Meeussen, V. A. Tett, "Biodegradation of metal cyanides by mixed and pure cultures of fungi," Enzyme. Microb. Technol, vol.22, no. 4, pp. 223-231, 1998.

[49] 49. T. W. Lambert, 1. Guyn, S. E. Lane, "Development of local Knowledge of environmental contamination in sydney, nova scotia: Environmental health practice from an environmental justice perspective," Sci. Total Environ, vol. 368, no. 2-3, pp. 471-484, 2006.

[50] 50. F. Gurbuz, A. G. Karahan, A. Akcil H. Ciftci, "Degradation of cyanide by natural algae species. In: YankoHombach V, Arnold A, Hallock P, Ishman S, McGann M, Parker WC, editors. Extended Abstracts of the Third International Congress 'Environmental, Micropaleontology, Microbiology and Metobentholog”, EMMM'2002, September 1 - 6, Vienna, pp. 46-55, 2002.

[51] 51. K. A. Hagelstein, T. I. Mudder, "Strategies and standards for control of bird mortality atmining operations in the cyanide monograph," edited by T. Mudder, Mining Journal Books Limited, London, pp. 28, 1998. 
[52] 52. G. Hilson, "Small-scale mining and its socio-economic impact in developing countries," Natural Res. Forum, vol. 26, no. 1, pp. 3-13, 2002.

[53] 52. T. Mudder, J. Whitlock, "Biological treatment of cyanidation wastewaters. Minerals and metallurgical processing," Littleton, Colorado, USA: The Society of Mining, Metallurgy and Exploration (SME), pp. 161- 165, 1984.

[54] 53. ICMM, "Metals Environmental Risk Assessment Guidance," Annual Review 2007, http://www.thecdi.com/general.php, Assessed 22/09/2020, pp. 6, 2007.

[55] 54. D. Kemp, C. J. Bond, D. M. Franks, C. Cote, "Mining, water and human rights: making the connection," J Cleaner Prod, vol. 18, no. 15, pp. 1553-1562, 2010.

[56] 55. S. R. La Brooy, H. G. Linge G. S. Walker, "Review of gold extraction from ores," Min Eng, vol. 7, no. 10, pp. 1213-41, 1994.

[57] 56. T. Mudder, S. Miller, L. Russell, A. Cox D. McWharter, "The biopass system phase I: laboratory evaluation," The cyanide monograph. London: Mining Journal Books, pp.. 420-40, 1995.

[58] 57. T. Mudder, M. Botz and A. Smith,. "The chemistry and treatment of cyanidation wastes," 2nd ed. London: Mining Journal Books, pp. 1-12, 2001 b.

[59] 58. Gold Album "Cyanide: Gold's killing companion. Park Project Underground Report," 2006. http://www,moles.org, Assessed 23/09/2020, pp. 3, 2006.

[60] 59. F. Gurbuz, H. Ciftci, A. Akcil, A. G. Karahan, "Microbial detoxification of cyanide solutions: a new biotechnological approach using algae," Hydrometallurgy, vol. 72, no. 1-2, pp. 167-176, 2004.

[61] 60. G. L. Miessler, D. A. Tarr, "Inorganic Chemistry" 3rd Ed, $\quad$ Pearson/Prentice Hall publisher, ISBN 0-13035471-6, pp. 16-29, 2014

[62] 61. G. C. Miller, C. A. Pritsos, "Unresolved problems with the use of cyanide in open pit precious metal mining in proceedings of cyanide: social, industrial and economic aspects," the minerals, metals \& materials society annual meeting, New Orleans, Louisiana, pp. 12-15, 2001.

[63] 62. G. L. Miltzarek, C. H. Sampaio J. L. Cortina, "Cyanide recovery in hydrometallurgical plants: use of synthetic solutions constituted by metallic cyanide complexes," Min Eng, vol. 15, no. 1-2, pp. 75 -82, 2002.

[64] 63. G. L. Monekosso, Wilson, J. "Plasma thiocyanate and vitamin b12 in Nigerian patients with degenerative neurological disease," Lancet, vol. 287, no. 7446, pp. 1062-1064. 1996.

[65] 64. J.B. Mosher, L. Figueroa, "Biological oxidation of cyanide: a viable treatment option for the Minerals Processing Industry," Min Eng, vol. 9, no.5 , pp. 573 - 81. 1996.

[66] 65. G .M. Mudd, "The environmental sustainability of mining in Australia: key mega-trends and looming constraint,". Res Policy, vol. 35, no. 2, pp. 98-115, 2010.

[67] 66. T. Mudder, "The sources and environmental significance of low levels of cyanide', in short course on management of cyanide in mining," ACMRR, Perth, pp. 23-49, 1997.

[68] 67. North Mara Gold Project: Supplementary Environmental Management Plan (Nyabirama): Vol. 1: Main Report Earth Systems, pp. 47, 2002.

[69] 68. Y.B. Patil, K.M. Paknikar, "Removal and recovery of metal cyanides using a combination of biosorption and biodegradation processes,” Biotechnol Lett, vol. 21, no. 2, pp. 913-919 1999.

[70] 69. F. Sandoval, Small-Scale Mining in Ecuador. Mining, Minerals, and Sustain- able Development Working Paper (75). International Institute for Environment and Development, pp. 1-54. 2002.

[71] L. Shapiro, J. Ross, P. Adams, R. Keyzer, S, Hix, D. MacMorran, C. Cunningham, C. Eason, "Effectiveness of cyanide pellets for control of dama wallabies (Macropus eugenii),". New Zealand J. Ecol, vol. 35, no. 3, pp. 1-12, 2011.

[72] 71. R. Therivel, T. Ross, “Cumulative effects assessment: does scale matter?" Environ Impact Assess, vol. 27, no. 5, pp. 365-385, 2007.

[73] 72. M.M. Veiga, and R. Baker, "Protocols for Environmental and Health Assessment of Mercury Released by Artisanal and Small Scale Miners. Report to the Global Mercury Project: Removal of Barriers to Introduction of Clean Artisanal Gold Mining and Extraction Technologies," pp. 37. 2004.

[74] 73 G. Walker, M. Eames, "Environmental inequalities: Cross-cutting themes for the ESRC/NERC transdisciplinary seminar series on environmental inequalities," pp, 8, 2006. 
[75] 74. C. A. Young, C "yanide: Just The Facts, in: Proceedings of Cyanide: Social, Industrial and Economic Aspects. The Minerals, Metals \& Materials Society Annual Meeting," New Orleans, Louisiana, pp. 12-15, 2001.

[76] 75. USEPA, "Cyanide: Rev," Environ Contam Toxicol, vol. 107, no. 3, pp. 53-64. 1989.

[77] 76. Amankwah, R. K., Anim-Sackey, C. "Promoting cooperation between small and large-scale miners in Ghana," Mining Eng, vol. 56, no.4, pp. 36-39, 2004.

[78] 77. Crispin, G. "Environmental management in small scale mining in PNG. J. Cleaner Prod, vol. 11, no. 2, pp. 175$183,2003$. 